\title{
Urban Air Pollutant from Motor Vehicle Emissions in Kuala Lumpur, Malaysia
}

\author{
Siti Haslina Mohd Shafie, Mastura Mahmud* \\ Geography Programme, Faculty of Social Sciences and Humanities, Universiti Kebangsaan Malaysia, Bangi, 43600 \\ Selangor, Malaysia
}

\begin{abstract}
The increasing amount of motor vehicles that emit pollutants are contributing significantly to urban air pollution, be it in industrial or developing countries. This study investigates the emission of particulate matter $\left(\mathrm{PM}_{10}\right)$ from exhaust and nonexhaust sources and gaseous pollutants, such as carbon monoxide $(\mathrm{CO})$ and nitrogen oxide $\left(\mathrm{NO}_{\mathrm{x}}\right)$ from several different classes of motor vehicles in the tropical city of Kuala Lumpur. Air pollutants from fuel consumption were obtained from emission factors, while non-exhaust particulate matter was estimated from the United States Environmental Protection Agency (U.S. EPA) Compilation of Air Pollutant Emissions Factors (AP-42). The total PM $_{10}$ emissions from all classes of motor vehicles estimated from the tail-pipe exhaust was $1,029,883 \mathrm{~kg}$, while non-exhaust sources were $1,573,539 \mathrm{~kg}$. Emissions of $\mathrm{PM}_{10}$ from newly registered private cars was the most dominant at $214,427 \mathrm{~kg}$, followed by emissions from motorcycles at $118,582 \mathrm{~kg}$ in 2014. Private cars also contributed 14,605 kg of CO and 5,726 kg of $\mathrm{NO}_{\mathrm{x}}$ in 2014 , compared with $9,830 \mathrm{~kg}$ of $\mathrm{CO}$ and 3,854 $\mathrm{kg}$ of $\mathrm{NO}_{\mathrm{x}}$ in 2010. Comparison with other Organisation for Economic Co-operation and Development (OECD) countries shows that the total emissions for $\mathrm{PM}_{10}$ and $\mathrm{NO}_{\mathrm{x}}$ were lower in Malaysia than in most countries, but the CO emissions here were higher than in Asian countries such as Japan and Korea, as well as in other European countries. Various strategies and policies should be implemented by the local authorities and government agencies to reduce emissions from the transportation sector in urban areas to improve the quality of the urban environment, human health, and the urban community.
\end{abstract}

Keywords: Urban traffic; Gaseous emissions; Private cars; Urban pollution; Asia Pacific.

\section{INTRODUCTION}

The transportation sector is a major source of traffic pollution in the city center. High levels of economic growth, rapid urbanization, increasing disposable income, a variety of social and recreational activities, increasing private vehicles, and the distribution of dissimilar materials and resources have directly increased the demand for the transport sector and leading to a deteriorating urban air quality (Saboori et al., 2014; Shahbaz et al., 2015). These increasing emissions from the transportation sector are contributing factors to domestic air pollution, global climate change, human health problems, and ground-level ozone formation at both regional and national scales (Saija and Romano, 2002; Azam et al., 2016).

Epidemiological evidence has identified traffic pollution as a risk factor for adverse health outcomes, including respiratory disease incidences (Zhu et al., 2012; Laumbach and Kipen, 2014), cardiovascular diseases (Jerrett et al.,

\footnotetext{
${ }^{*}$ Corresponding author.

Tel.: 03-89215672; Fax: 03-89213334

E-mail address: mastura@ukm.edu.my
}

2013; Beelen et al., 2014; Su et al., 2019; Wei et al., 2019), and premature mortality ( $\mathrm{Su}$ et al., 2015). Thus, WHO estimates approximately 4.2 million premature death cases worldwide (WHO, 2018). Recently, a relationship between traffic pollution and other diseases such as cognition, mental health and dementia, and air pollution has been identified (Luyten et al., 2018; Shehab and Pope, 2019; Hu et al., 2020).

Generally, the major sources of urban air pollution to individual health are particulate matter (PM) and nitrogen dioxide $\left(\mathrm{NO}_{2}\right)$ through emission from vehicle exhaust (Ghaffarpasand et al., 2020). In 2016, on-road vehicles accounted for about $39 \%$ and $20 \%$ of total $\mathrm{NO}_{\mathrm{x}}$ and carbon monoxide (CO) emissions in the European Union (EU), and it is found those passenger vehicles are the major cause of NOx and $\mathrm{CO}$ emissions from road transportation (EEA, 2018). Meanwhile, motor vehicles using diesel fuel have been identified as a major contributor to high $\mathrm{NO}_{\mathrm{x}}$ emissions in Europe (Anttila et al., 2011; Henschel et al., 2015) beside $\mathrm{CO}$ and total hydrocarbons (THC) (Yang et al., 2020).

\section{Fuel Consumption and Motor Vehicle Emissions}

The transportation sector consumes about 48 million barrels of oil per day compared to the current global total of 
93 million barrels of oil a day from more than 1.5 billion motor vehicles (EIA, 2014). Fuel consumption is defined as the amount of fuel consumed per unit distance and expressed in litres $/ 100 \mathrm{~km}$. The lower value of fuel consumption by vehicles has shown that high savings occur (Mathew, 2014). The higher octane petrol is cooler and significantly produces lower nitrogen oxide $\left(\mathrm{NO}_{\mathrm{x}}\right)$ release levels (Al-Arkawazi, 2019).

Cheah et al. (2008) investigated that fuel consumption and emission of pollutants from motor vehicles recorded a reduction from 11.2 litres/100 kilometres in 2007 to 5.6 litres $/ 100 \mathrm{~km}$, while the sales-weighted average fuel economy increased from 21 miles per gallon (mpg) in 2007 to $42 \mathrm{mpg}$ by 2035 . The International Energy Agency (IEA) specified that energy consumption from the global transport sector and greenhouse gas emissions are expected to increase by approximately $50 \%$ by 2030 and $80 \%$ by 2050 (Huang et al., 2020). Higher fuel consumption in motor vehicles was detected at urban signalised intersections due to the frequent changing of vehicle modes of deceleration, acceleration, and stopping (Wu et al., 2020).

In Malaysia, private cars, motorcycles, light, and heavy vehicles are major contributors to deterioration in air quality, especially in urban areas. The total number of newly registered motor vehicles from 2004 to 2017 was 286,771,902 units, comprising five classes: passenger cars, motorcycles, vans/lorries, and taxis/buses (DOE, 2017). Motorcycles and passenger cars are the dominant classes of motor vehicles, with $6,572,366$ units in 2004 that increased by $35 \%$ to $11,989,591$ units in 2015 (DOE, 2015). The same situation was shown for passenger cars, with 5,911,752 units in 2004 that grew by $35 \%$ to $13,173,030$ units in 2017 (DOE, 2015, 2017).

Motor vehicles and traffic emissions are directly related to the fuel consumption caused by an incomplete combustion process in the engine system. Fuel consumption from the transport sector in Malaysia showed an upward annual trend, as evidence by the 5,386 kilotonnes of oil equivalent (ktoe) in 1998 that rapidly increased to 23,435 ktoe in 2015 (Energy Commission Malaysia, 2014). Combustion of fossil fuels from petrol, fuel oil, and natural gas in the internal combustion engine of a motor vehicle releases air pollutants, such as carbon monoxide $(\mathrm{CO})$, sulphur dioxide $\left(\mathrm{SO}_{2}\right)$, oxides of nitrogen $\left(\mathrm{NO}_{\mathrm{x}}\right)$, non-methane volatile organic compounds (NMVOC), and particulate matter (PM) (Ong et al., 2011; Azam et al., 2016). In addition, transport activities from private and goods vehicles emit about $20 \%$ of greenhouse gases (World Bank, 2014; Alshehrya and Belloumi, 2017).

In Malaysia, energy consumption directly relates to the transport sector, foreign direct investment, and pollutant emissions that resulted from positive economic growth (Department of Statistics Malaysia, 2011). Consequently, higher fossil fuel consumption in Malaysia resulted in a $6.7 \%$ increase in annual average growth from the transportation sector from 1971 to 2008 , which is comparable to Thailand at $6.6 \%$ and Indonesia at 6.3\% (Ghosh, 2010). The increased consumption of fossil fuels in Malaysia from 1960 to 2002 resulted from the increasing motor vehicle ownership, with an average of $6.7 \%$ for 1,000 persons (Dargay et al., 2007).
The energy use from the transportation sector from fossil fuels was estimated at $50 \%$ in Malaysia, which is the highest in ASEAN (Chandran and Foon, 2013). Traffic emissions are also influenced by rapid urbanisation that impacts the population, economic growth, and activity services, particularly in the city centres. According to the 10th Malaysia Plan, the rate of urbanisation in Malaysia has increased from $25 \%$ in 1960 to $65 \%$ in 2005 , with the expected increase of $75 \%$ of the population residing in the Klang Valley conurbation by 2020 (Kuala Lumpur City Hall, 2004).

Thus, the objective of this study is to calculate the emissions of particulate matter from the exhaust and nonexhaust and gaseous pollutants from the fuel consumption of the vehicle class passenger cars, motorcycles, buses, and goods transport from 2010 to 2014 in the metropolitan city of Kuala Lumpur. This study utilizes the top-down approach based on fuel consumption for $\mathrm{CO}$ and $\mathrm{NO}_{\mathrm{x}}$, and the bottomup approach (vehicle kilometre travelled (VKT) and number of vehicles) for particulates. The CO and NOx emissions from motor vehicle exhausts are calculated based on fuel consumption (Masjuki et al., 2004; Kakouei et al., 2012), while the particulates include the exhaust $\mathrm{PM}_{10}$ and nonexhaust source from paved roads. The different approach for $\mathrm{CO}$ and $\mathrm{NO}_{\mathrm{x}}$ are used, as they are gaseous pollutants from motor vehicles through the fuel combustion process as petrol and diesel directly affect the levels of $\mathrm{CO}$ and $\mathrm{NO}_{\mathrm{x}}$ released. For $\mathrm{PM}_{10}$ emissions from motor vehicle exhaust, it is estimated using VKT and number of vehicles (EIA, 2005) because the movement the motor vehicles or driving patterns directly influence the emission of $\mathrm{PM}_{10}$ (Rostampour, 2010). Thus, VKT is affected by the flow of traffic and traffic congestion. Furthermore, the number of vehicles also caused serious traffic congestion through different driving patterns. The $\mathrm{CO}, \mathrm{NO}_{\mathrm{x}}$, and $\mathrm{PM}_{10}$ emissions will be compared to the Organisation for Economic Co-operation and Development (OECD) countries to gauge the rank of an environmental indicator of urban Kuala Lumpur that represents a developing country. The identification of the vehicle class that contributes the most emissions to the atmosphere in Kuala Lumpur may help policymakers to adopt a strategy to reduce air pollutants and the impacts of climate change on the city.

\section{MATERIALS AND METHOD}

\section{Study Area: Urban Kuala Lumpur}

Kuala Lumpur (KL) is the federal capital of Malaysia and is a prominent and sophisticated city in Southeast Asia, acting as a centre of commercial and industrial activities (Ling et al., 2010; Teriman et al., 2010; Jamhari et al., 2014). Kuala Lumpur covers an area of 24,221 hectares and is located on the west coast of Peninsular Malaysia (Fig. 1). It has a total population of $1,627,172$ inhabitants and a density of over 6,800 persons per square kilometre (Teriman et al., 2010). More than $60 \%$ of Malaysians live in urban areas in 2010 and it is predicted to increase to $75 \%$ in 2020 (Shuid, 2004).

Kuala Lumpur city is situated in the Klang Valley or Kuala Lumpur Conurbation (KLC). Under the Kuala Lumpur 


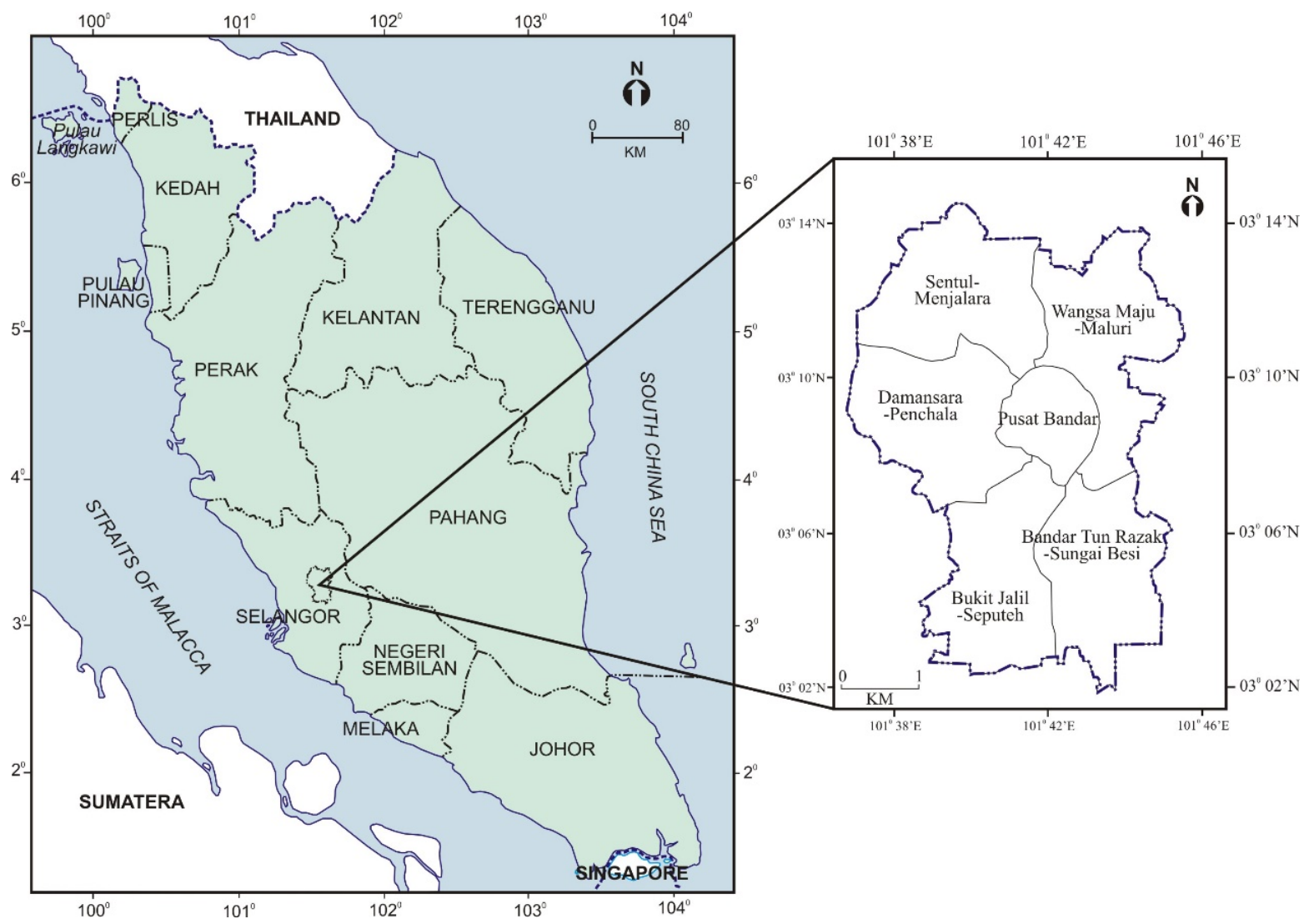

Fig. 1. Map of six strategic zones in Kuala Lumpur.

Structure Plan (2004-2020) and the Kuala Lumpur City Plan, it was divided into six strategic planning zones for the purposes of city planning (Architects and Urban Planners Malaysia, 2006) consisting the City Centre, Sentul-Menjalara, Wangsa Maju-Maluri, Damansara-Penchala, Bukit JalilSeputeh, and Bandar Tun Razak-Sungai Besi (Ling et al., 2012). Road transport represents $84 \%$ of the city's mobility, with private cars accounting for $57 \%$ of all motorised trips in Kuala Lumpur (Kuala Lumpur City Hall, 2004). Currently, Kuala Lumpur has a total of 1,213 kilometres of road length (Teriman et al., 2010). According to a report from the Public Work Department of Malaysia (2014), the overall road network in Kuala Lumpur, covering Kuala Lumpur-Kuala Selangor, Kuala Lumpur-Ipoh, Kuala Lumpur-Seremban Expressway, and Kuala Lumpur-Damansara, with a total length of $1,531.20 \mathrm{~km}$, had a traffic volume recorded at $1,083,320$ units for a 16-hour duration in 2010.

Newly annual registered motor vehicle data for Kuala Lumpur was provided by the Department of Road Transport Malaysia (MOT) at the Wangsa Maju branch. Data were classified to different categories and according to the fuel consumption of private cars and motorcycles (petrol), and buses and goods vehicles using diesel from the year 2010 to 2014. The exhaust emissions of $\mathrm{CO}$ and $\mathrm{NO}_{\mathrm{x}}$ are obtained from their fuel consumption, while particulate matter emission is estimated based on Baidya and Borken-Kleefeld (2009). The non-exhaust particulate matter from paved roads is calculated using the formula from the emission factors provided by the United States Environmental Protection
Agency (U.S. EPA) AP-42 (U.S. EPA, 2011).

\section{Fuel Consumption}

Fuel consumption for each vehicle class was analysed using Eq. (1) below by Kakouei et al. (2012):

$\mathrm{F}_{\mathrm{c}}=\mathrm{A}_{\mathrm{c}} \times \mathrm{V} \times \mathrm{R}_{\mathrm{d}}$

where:

$\mathrm{F}_{\mathrm{c}}=$ Fuel consumption in a day (diesel or petrol) in litres; $A_{c}=$ Average fuel consumption by each type of vehicle per kilometre $\left(\mathrm{L} \mathrm{km}^{-1}\right)$;

$\mathrm{V}=$ Number of each type of vehicle; and

$\mathrm{R}_{\mathrm{d}}=$ Amount of running per day by the vehicle $(\mathrm{km})$.

* The value of $\mathrm{Rd}$ is the number of vehicle trips $(\mathrm{km})$ per day and is estimated from the survey answered from 200 residents in Kuala Lumpur (Mohd Shafie, 2019). The small value of $\mathrm{Rd}$ is because it involves the average short-range distance performed by the residents of Kuala Lumpur. The average daily distance travelled is $14 \mathrm{~km}$.

The emissions of $\mathrm{CO}$ and $\mathrm{NO}_{\mathrm{x}}$ were next calculated from fuel consumption using Eq. (2) (Masjuki et al., 2004):

$\mathrm{TMi}=\mathrm{CF}(\mathrm{ES} \times \mathrm{FE} 1 \mathrm{p}+\mathrm{ES} \times \mathrm{FE} 2 \mathrm{p}+\mathrm{ES} \times \mathrm{FE} 3 \mathrm{p}+\ldots+$
$\mathrm{ES} \times \mathrm{FE} n \mathrm{p})$

where:

$\mathrm{TMi}=$ Total emission in year $\mathrm{i}(\mathrm{kg})$;

$\mathrm{ES}=$ Energy use in year of fuel type (ktoe); 
FE $\mathrm{n} / \mathrm{p}=$ Emission per unit energy of fuel type $\mathrm{n}\left(\mathrm{kg} \mathrm{GJ}^{-1}\right)$; $\mathrm{CF}=$ Conversion factor.

* The conversion factor $(\mathrm{CF})$ used in this study is 1 toe $=$ 41.86 GJ (UN, 1991; IEA, 2002; EIA, 2004).

* Energy use of fuel type (ES) in ktoe is calculated from the total registration of motor vehicles by year with energy use values derived from Malaysia Energy Statistics Handbook reports from 2010 and 2014 (Malaysian Energy Commission, 2017). The emission per unit energy of fuel type is constant according to pollutants for petrol and diesel as shown in Tables 1 and 2 .

Therefore, this study only estimated emissions from private cars using petrol and not diesel. Data from the Department of Road Transport Malaysia (MOT) showed that the total number of private cars using petrol is 10,906,065 units $(62.37 \%)$ compared to 148,207 units of diesel cars $(0.84 \%)$ from 2010 to 2014 .

\section{Particulate Matter Emissions}

Particulate matter emissions from road vehicles comprise emissions from tailpipe exhaust and non-exhaust emissions such as brake, tires and clutch, and re-suspension of dust (Thorpe and Harrison, 2008). Particulate emissions from the surface of paved roads via the movement of motor vehicles are estimated by using the following equation from U.S. EPA AP-42 (U.S. EPA, 2011). Default values used in this analysis: $\mathrm{k}=4.6, \mathrm{sL}=0.62 \mathrm{~g} \mathrm{~m}^{-2}, \mathrm{~W}=3.4$ tonnes (U.S. EPA, 2011).

$\mathrm{E}=\mathrm{k}(\mathrm{sL})^{0.91} \times(\mathrm{W})^{1.02}$

where:

$\mathrm{E}=$ Particulate emission factor (units match the units of $\mathrm{k}$ ); $\mathrm{k}=$ Particle size multiplier for particle size range and units of interest;

$\mathrm{sL}=$ Road surface silt loading (grams per square meter) $\left(\mathrm{g} \mathrm{m}^{-2}\right)$; and

$\mathrm{W}=$ Average weight (tonnes) of vehicles traveling the road.

Meanwhile, particulate matter emission from vehicle exhaust is based on mainly the fuel consumption (petrol and diesel), vehicle kilometre travelled (VKT), and emission factors. VKT is derived from Eq. (4) (EIA, 2005) and emission factor using Eq. (5).

$\mathrm{VKT}=$ Number of vehicles $\mathrm{x}$ Distance travelled

$\mathrm{E}_{\mathrm{P}}=\sum(\mathrm{N} \times \mathrm{VKT} \times \mathrm{e})$

where,

$E_{P}=$ Total emissions $E$ of a pollutant $p$;

$\mathrm{N}=$ Number of vehicles (unit);
$\mathrm{VKT}=$ Average annual vehicle kilometer travelled $(\mathrm{km})$; $\mathrm{e}=$ Emission factor.

Emission factors for private cars and motorcycles (petrol) are obtained from Baidya and Borken-Kleefeld (2009) while buses and goods vehicle are based on Euro 4 emission limits for RON95 and RON97 in Malaysia (Table 3).

\section{RESULTS AND DISCUSSION}

\section{Motor Vehicles in Kuala Lumpur}

The total number of new motor vehicles registered from 2010 to 2014 consists of private cars, motorcycles, goods vehicles, and buses. The annual trend showed a continuous increase of $3.71 \%$ per year from 3,161,741 units in 2010 to $3,812,460$ units in 2014 (Fig. 2). The highest numbers of vehicle classes are the private cars and motorcycles, which recorded 10,906,065 units (an increase of 62.37\%) in 2014 and $6,030,752$ units in 2010. This is in contrast to a lower number of goods vehicle at 498,837 units or $2.85 \%$ increase, while buses showed a lower quantity of 48,113 units or $0.27 \%$ of the total vehicles.

The total newly registration motor vehicles in Kuala Lumpur significantly showed annual averaged VKT for private cars is highest year by year from $26,259,715 \mathrm{~km}$ in 2010 to $31,919,321 \mathrm{~km}$ in 2014 compared to other vehicles classes. In addition, motorcycles recorded an increasing annual averaged VKT of 14,658,117 $\mathrm{km}$ and reached $17,651,935 \mathrm{~km}$ beside $1,307,720 \mathrm{~km}$ to $1,371,397 \mathrm{~km}$ for goods transport during the study period (Table 4).

The total pollutants emitted by private cars, motorcycles, buses, and goods vehicles from 2010 to 2014 for $\mathrm{PM}_{10}$ (exhaust and non-exhaust), $\mathrm{CO}$, and $\mathrm{NO}_{\mathrm{x}}$ are $2,603,422 \mathrm{~kg}$, $80,875 \mathrm{~kg}$, and $33,437 \mathrm{~kg}$, respectively (Fig. 1). The total $\mathrm{PM}_{10}$ emissions from exhaust is $1,029,883 \mathrm{~kg}$ and $1,573,539 \mathrm{~kg}$ from non-exhaust from 2010 to 2014. Overall, non-exhaust $\mathrm{PM}_{10}$ emissions from private cars and motorcycles emit the highest total of $\mathrm{PM}_{10}$ in 2014 at $214,427 \mathrm{~kg}$ and $118,582 \mathrm{~kg}$, respectively. This is followed by tailpipe $\mathrm{PM}_{10}$ emission of $142,952 \mathrm{~kg}$ from private cars and $79,055 \mathrm{~kg}$ by motorcycles in 2014. Meanwhile, goods vehicles released 9,212 kg of $\mathrm{PM}_{10}$ in 2014. Buses also showed similar conditions but in minimal quantities from $864 \mathrm{~kg}$ in 2010 to $869 \mathrm{~kg}$ in 2014 .

\section{Transport Emissions in Kuala Lumpur}

The CO emission from private cars was high, which was about 14,605 kg in 2014 in contrast to $9,830 \mathrm{~kg}$ in 2010 . Additionally, goods vehicles and buses produced $\mathrm{CO}$ emissions of $72 \mathrm{~kg}$ and $69 \mathrm{~kg}$ in 2010 , respectively, from which the numbers had slightly increased to $79 \mathrm{~kg}$ and $70 \mathrm{~kg}$, respectively, in 2014. Similarly, $\mathrm{NO}_{\mathrm{x}}$ also accounted for the

Table 1. Energy use for fuel type and motor vehicle (ES) in ktoe.

\begin{tabular}{|c|c|c|c|c|c|}
\hline Motor vehicle & 2010 & 2011 & 2012 & 2013 & 2014 \\
\hline Motorcycles (petrol) & 9560 & 8155 & 10843 & 12656 & 12705 \\
\hline Private cars (petrol) & 9560 & 8155 & 10843 & 12656 & 12705 \\
\hline Buses (diesel) & 8388 & 8712 & 9410 & 9568 & 10161 \\
\hline Goods transport (diesel) & 8388 & 8712 & 9410 & 9568 & 10161 \\
\hline
\end{tabular}

Source: Malaysian Energy Commission, 2017. 
Table 2. Emission per unit energy of fuel type for petrol and diesel (FE) $\left(\mathrm{kg} \mathrm{GJ}^{-1}\right)$.

\begin{tabular}{llc}
\hline \multirow{2}{*}{ Fuel Type } & \multicolumn{2}{c}{ Emission } \\
\cline { 2 - 3 } & $\mathrm{CO}$ & $\mathrm{NO}_{\mathrm{x}}$ \\
\hline Petrol & 3.490 & 1.368 \\
Diesel & 0.102 & 0.284 \\
\hline
\end{tabular}

Table 3. Emission factor for $\mathrm{PM}_{10}$ emission from exhaust according to fuel type and motor vehicles classes.

\begin{tabular}{ll}
\hline Motor vehicle class & $\mathrm{EF}\left(\mathrm{g} \mathrm{km}^{-1}\right)$ \\
\hline Private cars (petrol) & 0.06 \\
Motorcycles (petrol) & 0.06 \\
Buses (diesel) & 0.025 \\
Goods vehicle (diesel) & 0.025 \\
\hline
\end{tabular}

high emission from private cars and motorcycles with $5,726 \mathrm{~kg}$ and $1,750 \mathrm{~kg}$ compared with $3,854 \mathrm{~kg}$ and $1,200 \mathrm{~kg}$, respectively, from 2010 to 2014 (Table 5).

The highest $\mathrm{PM}_{10}$ emissions in Kuala Lumpur were from private cars and motorcycles during peak hours at 0700 to 0900 and at around $1700 \mathrm{hr}$ to $2000 \mathrm{hr}$ in the morning and evening, respectively (Azhari et al., 2018). This significantly increased the emissions due to the minimum speed limits of the vehicles and stop-and-go vehicle in traffic lights (Madireddy et al., 2011). Individual attitude and driving patterns, characteristics and types of vehicles, the physical aspect of road surface, average vehicle speed, as well as traffic conditions all affect the rate of emissions (Barth and Boriboonsomsin, 2009).

Generally, $\mathrm{CO}$ and $\mathrm{NO}_{\mathrm{x}}$ pollutants are emitted from fuel consumption in vehicle movement process, with diesel fuel producing higher emissions than petrol. However, the emission from petrol fuel is also attributed by the high number of motor vehicles compared with goods vehicles that consume diesel in Kuala Lumpur. Vehicles of less than five years with newer engine technology can reduce $\mathrm{CO}$ and $\mathrm{NO}_{\mathrm{x}}$ emissions by $71 \%$ and $10 \%$, respectively (Clark et al., 2002).

Taxi was excluded in this study, where it cumulatively accounted for only 335 units in 2010, which increased to 336 units in 2014, through the use of natural gas (natural gas vehicles or NGV) in Kuala Lumpur. Furthermore, the rapid growth of mobile technology and smartphone applications significantly led various companies to develop relationships with consumers through mobile applications (Zhang, 2017; Chin and Lai, 2018). For example, MyTeksi was introduced in Kuala Lumpur and was subsequently branded as GrabTaxi in 2011. Then, GrabCar was officially launched in Malaysia following the increasing use of GrabCar due to usage of safety, time efficiency, and convenience to passengers and drivers alike in 2014 (Jayaraj et al., 2019).

In Malaysia, Grab was launched in 2012 as a third-party taxi e-hailing mobile application (Lin and Dula, 2016). Report from The Land Public Transport Commission (SPAD) summarized that $80 \%$ of the public are more likely to use Uber and GrabCar services due to high accessibility factors (New Straits Times, 2017). Today, Grab is the best platform for driving individual day trips mostly for drivers and passengers to choose and use the Grab application in Southeast Asia. Therefore, using taxis for mobility is deemed impractical and not the popular choice for Kuala Lumpur residents.

The Organisation for Economic Co-operation and Development (OECD, 2019) also released information on the road transport emissions of $\mathrm{CO}, \mathrm{NO}_{\mathrm{x}}$, and $\mathrm{PM}_{10}$ (Table 6). The list of countries included for comparison are Germany, which represents an industrialised European nation; Chile and New Zealand, which represent the countries in the Southern Hemisphere; while Japan and Korea represent the Asian Pacific countries. No information is available for ASEAN countries. Germany recorded the high emissions of $\mathrm{PM}_{10}$, $\mathrm{NO}_{x}$, and $\mathrm{CO}$ in 2010 but displayed a decreasing trend in 2014. Asian countries, such as Korea, also showed a similar

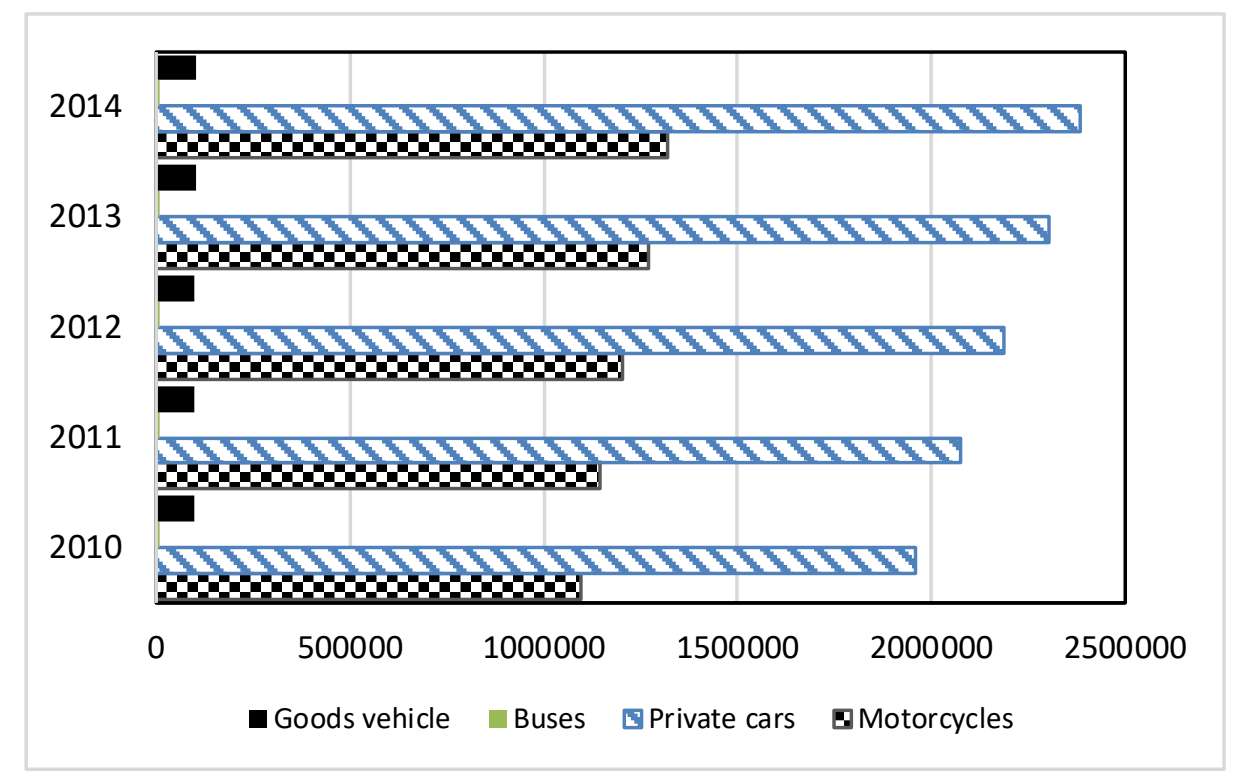

Fig. 2. Annual total ownership registration of motor vehicles in Kuala Lumpur (2010-2014). 
Table 4. Annual vehicle kilometer travelled (VKT) in Kuala Lumpur (2010-2014).

\begin{tabular}{lll}
\hline Vehicle Class & Total vehicle registered (unit) & Averaged annual VKT $(\mathrm{km})$ \\
\hline 2010 & $1,094,113$ & \\
Motorcycles & $1,960,081$ & $14,658,117$ \\
Private cars & 9,601 & $26,259,715$ \\
Buses & 97,611 & $1,286,27$ \\
Goods vehicle & & $1,307,720$ \\
2011 & $1,143,270$ & $15,316,686$ \\
Motorcycles & $2,0736,15$ & $27,780,760$ \\
Private cars & 9,611 & 128,761 \\
Buses & 98,505 & $1,319,697$ \\
Goods vehicle & & \\
2012 & $1,204,920$ & $16,142,627$ \\
Motorcycles & 2188458 & $29,319,341$ \\
Private cars & 9616 & 128,828 \\
Buses & 99467 & $1,332,585$ \\
Goods vehicle & & \\
2013 & $1,270,871$ & $17,026,190$ \\
Motorcycles & $2,301,385$ & $30,832,254$ \\
Private cars & 9,629 & 129,002 \\
Buses & 100,890 & $1,351,650$ \\
Goods vehicle & $1,317,578$ & $17,651,935$ \\
2014 & $2,382,526$ & $31,919,321$ \\
Motorcycles & 9,656 & 129,364 \\
Private cars & 102,364 & $1,371,397$ \\
Buses & &
\end{tabular}

Table 5. Gaseous and $\mathrm{PM}_{10}$ emissions (kg) from new registered vehicles in Kuala Lumpur (2010-2014).

\begin{tabular}{lllllll}
\hline Pollutant & Class/Years & 2010 & 2011 & 2012 & 2013 & 2014 \\
\hline PM $_{10}$ & Private cars & 117605 & 124417 & 131307 & 138083 & 142952 \\
(exhaust) & Motorcycles & 65647 & 68596 & 72295 & 76252 & 79055 \\
& Buses & 240 & 240 & 240 & 241 & 241 \\
& Goods vehicle & 2440 & 2463 & 2487 & 2522 & 2559 \\
& Total & $\mathbf{1 8 5 9 3 2}$ & $\mathbf{1 9 5 7 1 6}$ & $\mathbf{2 0 6 3 3 0}$ & $\mathbf{2 1 7 0 9 8}$ & $\mathbf{2 2 4 8 0 7}$ \\
PM $_{10}$ & Private cars & 176407 & 186625 & 196961 & 207125 & 214427 \\
(non-exhaust) & Motorcycles & 98470 & 102894 & 108443 & 114378 & 118582 \\
& Buses & 864 & 865 & 865 & 867 & 869 \\
& Goods vehicle & 8785 & 8865 & 8952 & 9080 & 9213 \\
& Total & $\mathbf{2 8 4 5 2 7}$ & $\mathbf{2 9 9 2 5 0}$ & $\mathbf{3 1 5 2 2 1}$ & $\mathbf{3 3 1 4 5 0}$ & $\mathbf{3 4 3 0 9 1}$ \\
$\mathrm{CO}$ & Private cars & 9830 & 11003 & 12323 & 13628 & 14606 \\
& Motorcycles & 3061 & 3344 & 3735 & 4154 & 4465 \\
& Buses & 70 & 69 & 70 & 70 & 71 \\
& Goods vehicle & 72 & 73 & 75 & 77 & 79 \\
NO $_{\mathrm{x}}$ & Total & $\mathbf{1 3 0 3 4}$ & $\mathbf{1 4 4 9 0}$ & $\mathbf{1 6 2 0 3}$ & $\mathbf{1 7 9 3 0}$ & $\mathbf{1 9 2 2 0}$ \\
& Private cars & 3854 & 4314 & 4832 & 5344 & 5727 \\
& Motorcycles & 1200 & 1311 & 1465 & 1629 & 1751 \\
& Buses & 193 & 191 & 194 & 194 & 195 \\
& Goods vehicle & 200 & 203 & 207 & 213 & 220 \\
& Total & $\mathbf{5 4 4 8}$ & $\mathbf{6 0 2 0}$ & $\mathbf{6 6 9 8}$ & $\mathbf{7 3 8 0}$ & $\mathbf{7 8 9 3}$
\end{tabular}

trend, where the $\mathrm{CO}$ and $\mathrm{NO}_{\mathrm{x}}$ emissions in 2010 had further reduced to 409.218 thousand tonnes and 335.721 thousand tonnes in 2014, respectively. Improved green technology can be attributed to the declining trend of emissions.

For Malaysia, the emission data obtained from the Department of Environment had shown a significantly lower number compared with other OECD countries for $\mathrm{PM}_{10}$, while the annual newly registered vehicles in Kuala Lumpur represent approximately $6 \%$ of the emissions. The increasing trend is small compared with other OECD nations. As a developing country, Malaysia displayed higher $\mathrm{CO}$ emissions from the transport sector at 1,597 tonnes in 
Table 6. Comparison of road transport emissions (thousand tonnes) in Malaysia and selected OEDC countries (2010-2014).

\begin{tabular}{lllllllllll}
\hline \multirow{2}{*}{ Pollutant } & Year & Germany & Canada & Iceland & Chile & Japan & Korea & $\begin{array}{l}\text { New } \\
\text { Zealand }\end{array}$ & $\begin{array}{l}\text { Malaysia } \\
\text { L }\end{array}$ & $\begin{array}{l}\text { Kuala } \\
\text { Lumpur }\end{array}$ \\
\hline PM $_{10}$ & 2010 & 34.41 & 33.88 & 0.19 & 1.88 & NA & 15.26 & NA & 4.49 & 0.003 \\
& 2011 & 33.47 & 32.90 & 0.17 & 1.86 & NA & 13.03 & NA & 4.44 & 0.003 \\
& 2012 & 31.95 & 31.80 & 0.17 & 1.77 & NA & 12.97 & NA & 4.59 & 0.003 \\
& 2013 & 31.07 & 31.49 & 0.16 & 2.26 & NA & 12.10 & NA & 4.34 & 0.003 \\
NO $_{x}$ & 2014 & 30.30 & 30.06 & 0.15 & 2.54 & NA & 10.02 & NA & 4.27 & 0.003 \\
& 2010 & 537.08 & 562.68 & 3.00 & 61.19 & 397.55 & 368.05 & 69.38 & 213.79 & 0.005 \\
& 2011 & 523.16 & 550.22 & 2.58 & 65.40 & 410.90 & 382.23 & 71.41 & 216.43 & 0.006 \\
& 2012 & 506.13 & 529.67 & 2.40 & 66.76 & 371.21 & 322.31 & 72.33 & 226.21 & 0.007 \\
$\mathrm{CO}^{*}$ & 2013 & 495.61 & 492.88 & 2.34 & 75.58 & 339.06 & 345.67 & 72.35 & 220.79 & 0.007 \\
& 2014 & 493.12 & 469.02 & 2.37 & 80.37 & 313.92 & 335.72 & 73.69 & 223.05 & 0.008 \\
& 2010 & 971.93 & $2,318.37$ & 9.43 & 305.69 & 618.92 & 583.72 & 519.98 & 1597.96 & 0.013 \\
& 2011 & 907.01 & $2,209.95$ & 8.07 & 469.42 & $1,092.91$ & 520.39 & 524.09 & 1671.00 & 0.014 \\
& 2012 & 884.37 & $2,011.03$ & 7.21 & 480.02 & 944.54 & 463.54 & 516.13 & 1779.40 & 0.016 \\
& 2013 & 826.04 & $1,902.77$ & 6.38 & 360.70 & 973.83 & 442.67 & 505.93 & 1786.40 & 0.018 \\
\hline
\end{tabular}

NA: Not available.

2010 and 1,850 tonnes in 2014 (DOE, 2011, 2015). The increasing trend of $\mathrm{CO}$ and $\mathrm{NO}_{\mathrm{x}}$ emissions is mainly due to the increase in total motor vehicles, which mostly consume fossil fuel.

Malaysia should adopt more green transport initiatives since the trend of emissions of pollutants from the transportation sector in Malaysia is on the increase compared to other OEDC countries. Currently, approximately 90 percent of vehicles are fossil-fueled, hence the low number of environmental-friendly electric vehicles of less than 6,000 units on Malaysia roads (Md Khalili, 2019). China leads the market for electric vehicles with 2.3 million in 2018, followed by 1.3 million in Europe (IEA, 2019). In the US and Europe, mobile source emission controls such as exhaust after-treatment technologies for diesel and petrol vehicles that meet strict regulations have reduced emission (Winkler et al., 2018). Stricter Euro 6 emission limits for petrol and diesel were imposed in Europe since 2015 (The Automobile Association, 2020). Policies in some OECD countries to reduce emissions include a zero-emissions vehicles (ZEVs) mandate in Canada by 2030, while in Korea initiatives include national subsidies for low-carbon vehicle purchases in 2018, abatement and subsidies on vehicle taxes, decreased road tolls and municipal parking rates (IEA, 2019).

Some of the reasons why the usage of electric cars is in low demand is due to the limited options of cars available, the expensive price tag of the cars from the tax of imported vehicles imposed by the Malaysia government, the lack of public awareness on the importance of green technology and environmental-friendly modes of transport (Bernama, 2019).

In order to achieve a green technology nation, the government needs to implement comprehensive initiatives to achieve these targets such as those outlined in the National Electric Mobility Blueprint (2015-2030) (GreenTech, 2015). By 2030, the government aspires to attain 100,000 electric cars; 100,000 electric motorcycles and 2,000 electric buses on Malaysian roads, as well as 125,000 charging stations
(Bernama, 2019).

Malaysia should follow the industrialised OECD countries that had successfully reduced GHG and air pollutants from the road transport over the past ten years. Incentives for tax credits for those using green technologies, such as electric vehicles, should encourage more consumers to use affordable green vehicles that consume less fuel. The Malaysian Green Technology Corporation (MTDC) was charged to install 3,000 charging sites in government buildings, petrol stations, and shopping malls by 2018 to encourage for e-mobility of electric cars (Aswan, 2019), of which there were only 5,403 efficiency vehicle (EV) cars in March 2019. This is still below the target set by the National Electric Mobility Blueprint (2015) projection of 125,000 charging stations by 2030, where power supply for customers remains a problem (Zainuddin, 2019). Incentives were also given on energy efficiency vehicles (EEVI) and plug in hybrid efficiency vehicles (PHEV) as was implemented successfully in other Asian countries (China, Japan, India), Europe, and the USA. However, the growth of the EV industry in Malaysia is hampered by factors such as high price, slow infrastructure implementation, and technological limitation (Frost and Sullivan, 2019). Even the move by the Government of the United Kingdom to ban new sales of diesel vehicles by 2040 to achieve a sustainable, zero-carbon road transport system is considered too late by some (Shammut et al., 2019).

EVs offer zero $\mathrm{CO}_{2}$ tailpipe emissions and the highest energy efficiency compared to a fuel-based car that produced $152 \mathrm{~g} \mathrm{~km}^{-1}$, a saving of 1.7 million tonnes of $\mathrm{CO}_{2}(\mathrm{GreenTech}$, 2015). Among the positive impacts of electric vehicles (EV) are the decline in human toxicity exposure to ozone, and reduction in particulate matter formation which improves air quality as EV performs 8 times better than the Euro 6 diesel vehicles (Hooftman et al., 2016).

It is estimated that a battery electric vehicle $(\mathrm{BEV})$ produces lower $\mathrm{NO}_{\mathrm{x}}$ emission of $36 \mathrm{mg} \mathrm{km}^{-1}$ (based on $2016 \mathrm{US}$ electric grid) compared to Euro 6 petrol of $60 \mathrm{mg} \mathrm{km}^{-1}$. Green vehicles will emit zero particulates and CO compared to the 
$0.3 \mathrm{mg} \mathrm{km}{ }^{-1}$ emission of particulates and $500 \mathrm{mg} \mathrm{km}^{-1}$ of $\mathrm{CO}$ from the Euro 6 petrol (Winkler et al., 2018). The emission reduction potential from the transportation sector would be beneficial to Malaysia environmentally when there is mass usage of EV as the air quality will be improved from zero emission of $\mathrm{CO}$ and particulate matter, and $\mathrm{NO}_{\mathrm{x}}$ emission that will be halved.

Kuala Lumpur City Hall (KLCH) is a member of the C40 Cities Climate Leadership. Indeed, the issue of climate change has significantly encouraged the development of more intensive, practical, and integrated acts, policies, and strategies by policymakers and stakeholders in Malaysia. The Kuala Lumpur Low Carbon Society Blueprint 2030 was developed as its commitment to reduce emissions by $70 \%$ by 2022 against 2015 levels (Ho et al., 2018). This amounts to a decrease in cumulative emissions of $134,345 \mathrm{tCO}_{2} \mathrm{e}$ and a financial saving in energy cost of RM76.1 million over this period of time. Some of the national policies in place include the national target of $40 \%$ emissions intensity reduction, Renewable Energy Act, National Green Technology Policy, National Energy Efficiency Plan, and National Policy on Climate Change. It has also committed to a target of $45 \%$ carbon intensity reduction by 2030 (relative to 2005 levels) (Kuala Lumpur City Hall, 2017).

In addition to the policies, the implementation of emission reduction focusing on the petrol quality of Euro in Malaysia would be impactful in reducing the amount of air pollutants emitted to the surrounding environment with the implementation of the two types of octane rating fuel for petrol in Malaysia, namely RON95 and RON97. The Euro 4M RON97 commenced in September 2015, as well as the Euro 5 diesel since November 2014. Following the Malaysian government's directive for the implementation of Euro 4M by 1 January 2020, petrol operators such as Shell, Caltex, Petron and Petronas have introduced the new fuel standard of RON95 petrol at their stations. The price of RON95 had increased steadily since it replaced the lower octane RON92 in 2008 due to the gradual reduction in fuel subsidies by the government (The Central Bank of Malaysia, 2011; Omar Kamil, 2015; Shaari et al., 2018; Yunus et al., 2019).

The RON95 petrol produced lower $\mathrm{NO}_{\mathrm{x}}$ emissions by $7.7 \%$ compared to RON97 but produced higher emissions of CO (36.9\%) and HC (20.3\%) (Salleh et al., 2018). The CO emission from RON97 is also reduced from $4 \%$ to $3 \%$, while the reduction from RON95 petrol is from $3 \%$ to $2.8 \%$ based on the fuel characteristics such as density, octane number and lower heating value (Salleh et al., 2018). Engine speed also reduces the $\mathrm{CO}$ emissions from the RON95 petrol by $10 \%$ lower than the RON97 petrol.

The sulphur limit for petrol and diesel in Malaysia was still high at $500 \mathrm{ppm}$ in 2007, which coincides with the Euro 2 Standard (Atiqah et al., 2018). Ramalingam and Fuad (2014) found that $60 \%$ of diesel samples had sulphur levels above $1000 \mathrm{ppm}$ in 2006, followed by $67 \%$ in 2007 and $26 \%$ in 2009 . However, the concentration of sulphur in all diesel samples in 2011, 2012, 2013 and 2014 were lower than $500 \mathrm{ppm}$ and this value was eight times higher than Euro 4 Standards in Peninsular Malaysia (Ramalingam and Fuad, 2014). Atiqah et al. (2018) also summarized that
Diesel Euro 2 (EDE2) significantly improved the engine fuel consumption by $7.39 \%$ and for exhaust emissions, EDE2 produced slightly higher $\mathrm{NO}_{\mathrm{x}}$ and $\mathrm{CO}$ in Malaysia. In addition, the U.S. EPA informed that approximately $2 \%$ of sulphur from diesel fuel also produces PM emission (Stanislaus et al., 2010).

Malaysia introduced the Euro 2M fuel Standard in 2009, whereby the fuel properties are controlled by the Environmental Quality (Control of Petrol and Diesel Properties) Regulations 2007 (Environmental Quality Act 1974, 1974). Since then, all oil companies in Malaysia were required to upgrade their fuel quality to comply with the Euro 2 Standard. Formerly, the sulphur limit was 3,000 ppm for diesel and 1,500 ppm for gasoline (Asian Development Bank 2006). Hence, the Malaysian government recommends lower sulphur to ensure that vehicles use fuels that comply with the Euro 2 Standard. On the other hand, growth in vehicle numbers and modern emission reduction technology demand an adequate supply of low sulphur fuel at levels of $50 \mathrm{ppm}$ and $10 \mathrm{ppm}$. However, Malaysia moved towards Euro 4 Standard implementations as the next step forward in fuel quality improvement. The Euro 4 Standard restricts sulphur content to a maximum of $50 \mathrm{ppm}$ in fuels (Ramalingam and Fuad, 2014).

The diesel Euro 5M was introduced to the Malaysian market by some oil and gas companies in 2016 (Atiqah et al., 2018). Diesel Euro 5M is a cleaner fuel due to its lower content of sulphur compared with diesel Euro 2M (Stanislaus et al., 2015). The benzene level in the Malaysian Euro 4M is specified at $3.5 \%$ by volume, in contrast to the Euro 4 specification for a benzene content of $1 \%$ maximum by volume (Asian Clean Fuel Association, 2012). The sulphur content for Euro $4 \mathrm{M}$ was set at $50 \mathrm{ppm}$, similar to Euro 4 . The $\mathrm{NO}_{\mathrm{x}}$ emissions for Euro $4 \mathrm{M}$ is capped at $0.15 \mathrm{~g} \mathrm{~km}^{-1}$ for petrol passenger cars, in comparison to the equivalent figures for Euro 4 at $0.08 \mathrm{~g} \mathrm{~kg}^{-1}$ or the more stringent Euro 5, with $\mathrm{NO}_{\mathrm{x}}$ emission capped at $0.06 \mathrm{~g} \mathrm{~km}^{-1}$ (Asian Clean Fuel Association, 2012).

\section{Uncertainty}

Among the uncertainties that arise from this study is that only the new motor vehicles registered in the Kuala Lumpur metropolitan area are considered, which is a small scope on the air quality study of pollutant emissions from motor vehicles for a short period from 2010 to 2014 . Notwithstanding, this study does not focus on the older motor vehicles, where age is identified as a major contributor to pollution emissions (Caserini et al., 2013), rather, this study examines the fuel consumption in the process of vehicle movement. Zachariadis et al. (2001) assumed that both the specific mileage, for example, kilometre per vehicle, and the emission factors are independent of vehicle age and therefore independent of time. Experimental emissions data from in-use cars indicated a clear deterioration in the emission behaviour as cars became older, mainly because of the ageing of their catalytic converters and degradation of their emission control systems (Lawson, 1993; Samaras et al., 1998; Ntziachristos and Samaras, 2000). Therefore, age and technological changes determine the internal dynamics of the motor vehicle 
population and influence the environmental impact of road transport in various ways. Uncertainty also arises from the average vehicle mileage travelled from the mileage variation, which is estimated up to $3 \%$ for $\mathrm{NO}_{\mathrm{x}}$ and approximately $12 \%$ for $\mathrm{CO}$ as well as the emission factors that also contribute to the uncertainty in calculating the emission of pollutants (Baidya and Borken-Kleefeld, 2009).

\section{CONCLUSION}

Urban traffic pollution has resulted from various factors such as urbanisation, population, and the economy of the country. The $\mathrm{PM}_{10}$ emissions from private cars contribute to air pollution with $214,427 \mathrm{~kg}$ released in 2014 . The highest $\mathrm{PM}_{10}$ emission in Kuala Lumpur was contributed by private cars and motorcycles that resulted from traffic congestion, differences of fuel characteristic in vehicle movement processes, and morphology aspects of the urban background. The growth of EV industry in Malaysia should be encouraged by reducing the exorbitant price of cars, improving the charging infrastructure, and through other strategies implemented by other nations, such as tax incentives on green technological vehicles, which could be one of the ways forward for government agencies to control the negative impact of urban traffic pollution, especially towards human health and urban community.

\section{REFERENCE}

Al-Arkawazi, S.A.F. (2019). The petrol fuel quality impact on fuel consumption, air-fuel ratio (AFR), lambda $(\lambda)$ and exhaust emissions of petrol-fueled vehicles. Cogent Eng. 6: 1-22. https://doi.org/10.1080/23311916.2019.1616866

Alshehrya, A.S. and Belloumi, M. (2017). Study of the environment Kuznets curve for transport carbon dioxide emissions in Saudi Arabia. Renewable Sustainable Energy Rev. 75: 1339-1347. https://doi.org/10.1016/j.rser.2016.1 1.122

Anttila, P., Tuovinen, J.P. and Niemi, J.V. (2011). Primary $\mathrm{NO}_{2}$ emissions and their role in the development of $\mathrm{NO}_{2}$ concentrations in a traffic environment. Atmos. Environ. 45: 986-992. https://doi.org/10.1016/j.atmosenv.2010.1 0.050

Architects and Urban Planners Malaysia (AJM) (2006). Kuala Lumpur Local Plan-Findings Report. Unpublished report. Kuala Lumpur City Hall.

Asian Clean Fuel Association (2012). InFocus: Malaysia to Implement Euro 4M in 2015. https://www.acfa.org.sg/pdf/ InFocus $8 \% 202012$ 06\%20Malaysia.pdf

Asian Development Bank (2006). Malaysia-Clean Air Initiative 2006. Country Synthesis Report on Urban Air Quality Management. Malaysia. Discussion Draft. https://www.cleanairnet.org/caiasia/1412/csr/malaysia.pdf

Aswan, M. (2019). ChargEV is driving Malaysia's electric vehicle infrastructure. Carlist, 13 September 2019. https://www.carlist.my/news/chargev-is-driving-malaysias-electric-vehicle-infrastructure-66003/66003/

Atiqah, N., Jazair, W., Muhsin, A. and Hasannuddin, A.K. (2018). Performance and emissions of light-duty diesel vehicle fuelled with non-surfactant low grade diesel emulsion compared with a high grade diesel in performance and emissions of light-duty diesel vehicle fuelled with non-surfactant low grade diesel emulsion compared with a high grade diesel in Malaysia. Energy Convers. Manage. 130: 192-199. https://doi.org/10.1016/ j.enconman.2016.10.057

Azam, M., Othman, J. and Ara, R. (2016). Energy consumption and emission projection for the road transport sector in Malaysia: An application of the LEAP model. Environ. Dev. Sustain. 18: 1027-1047. https://doi.org/10.1007/s10 668-015-9684-4

Azhari, A., Talib, M. and Fariz, A. (2018). Road traffic as an air pollutant contributor within an industrial park environment. Atmos. Pollut. Res. 9: 680-687. https://doi.org/10.1016/j.apr.2018.01.007

Baidya, S. and Borken-Kleefeld, J. (2009). Atmospheric emissions from road transportation in India. Energy Policy 37: 3812-3822. https://doi.org/10.1016/j.enpol.20 09.07.010

Barth, M. and Boriboonsomsin, K. (2009). Traffic congestion and greenhouse gases. Access 35: 2-9. https://www.acce ssmagazine.org/fall-2009/traffic-congestion-greenhousegases/

Beelen, R., Stafoggia, M., Raaschou-Nielsen, O., Andersen, Z.J., Xun, W.W., Katsouyanni, K. and Hoek, G. (2014). Long-term exposure to air pollution and cardiovascular mortality: An analysis of 22 European Cohorts. Epidemiology 25: 368-378. https://doi.org/10.1097/EDE. 0000000000000076

Bernama (2019). Green transport the way forward. https://www.nst.com.my/cbt/2019/10/530681/green-tran sport-way-forward

Caserini, S., Pastorello, C., Gaifani, P. and Ntziachristos, L. (2013). Impact of the dropping activity with vehicle age on air pollutant emissions. Atmos. Pollut. Res. 4: 282289. https://doi.org/10.5094/APR.2013.031

Chandran, V.G.R. and Foon, C. (2013). The impacts of transport energy consumption, foreign direct investment and income on $\mathrm{CO}_{2}$ emission in ASEAN-5 economies. Renewable Sustainable Energy Rev. 24: 445-453. https://doi.org/10.1016/j.rser.2013.03.054

Cheah, L., Evans, C., Bandivadekar, A. and Heywood, J. (2008). Factor of two: Halving the fuel consumption of New U.S. Automobiles by 2035. In Reducing climate impacts in the transportation sector, Cannon, J. and Sperling, D. (Eds), Springer, Dordrecht. http://web.mit.ed u/sloan-auto-lab/research/beforeh2/files/cheah_factorTwo. pdf

Chin, T.A. and Lai, L.Y. (2018). Determinants of brand image and their impacts on purchase intention of Grab. $J$. Arts Soc. Sci. 2: 26-36. https://ruijass.com/wp-content/up loads/2018/03/3-003TICFinal.pdf

Clark, N.N., Kern, J.M., Atkinson, C.M. and Nine, R.D. (2002). Factors affecting heavy-duty diesel vehicle emissions. J. Air Waste Manage. Assoc. 52: 84-94. https://doi.org/10.1080/10473289.2002.10470755

Dargay, J., Gately, D. and Sommer, M. (2007). Vehicle ownership and income growth, worldwide: 1960-2030. 
Energy J. 28: 143-170. https://www.jstor.org/stable/4132 3125

Department of Environment (DOE) (2011). Malaysia environmental quality report 2011. Department of Environment, Putrajaya, Malaysia.

Department of Environment (DOE) (2015). Malaysia environmental quality report 2015. Department of Environment, Putrajaya, Malaysia.

Department of Environment (DOE) (2017). Malaysia environmental quality report 2017. Department of Environment, Putrajaya, Malaysia.

Department of Statistics Malaysia (2011). Population distribution and basic demographic characteristicspopulation and housing census of Malaysia 2010. Department of Statistics Malaysia. Putrajaya, Malaysia.

EEA (2018). European Union Emission inventory report 1990-2016 under the UNECE Convention on Long-range Transboundary Air Pollution (LRTAP). European Environment Agency. https://www.eea.europa.eu/publicati ons/european-union-emission-inventory-report-1990-2016

Energy Commission Malaysia (2014). National energy balance 2014. https://meih.st.gov.my/documents/10620/ 5bb0f85c-fc99-4743-a8a9-8ee0d65f1299

Environmental Quality Act 1974 (1974). Environmental Quality (Control of Petrol and Diesel Properties) Regulations 2007. P.U. (A) 145/2007, Federal Subsidiary Legislation, Percetakan National Berhad, Lawnet.

Frost and Sullivan (2019). Malaysian eMobility Sector in the Context of Electric Vehicle (EV) Developments in Southeast Asia, Forecast to 2022. https:/www.reportlink er.com/p05778491/Malaysian-eMobility-Sector-in-the-Co ntext-of-Electric-Vehicle-EV-Developments-in-SoutheastAsia-Forecast-to.html

Ghaffarpasand, O., Beddows, D.C.S., Ropkins, K. and Pope, F.D. (2020). Real-world assessment of vehicle air pollutant emissions subset by vehicle type, fuel and Euro class: New findings from the recent UK EDAR field campaigns, and implications for emissions restricted zones. Sci. Total Environ. 734: 139416. https://doi.org/1 0.1016/j.scitotenv.2020.139416

Ghosh, S. (2010). Examining carbon emissions economic growth nexus for India: A multivariate co-integration approach. Energy Policy. 38: 3008-3014. https://doi.org/ 10.1016/j.enpol.2010.01.040

GreenTech (2015). National Electric mobility blueprint; positioning Malaysia as the 'electric mobility marketplace. Malaysian Green Technology Corporation. https://rise.esmap.org/data/files/library/malaysia/RE/12. 4\%20page\%2011.pdf

Henschel, S., Tertre, A.L., Atkinson, R.W., Querol, X., Pandolfi, M., Zeka, A., Haluza, D., Analitis, A., Katsouyanni, K. and Bouland, C. (2015). Trends of nitrogen oxides in ambient air in nine European cities between 1999 and 2010. Atmos. Environ. 117: 234-241. https://doi.org/10.1016/j.atmosenv.2015.07.013

Ho, C.S., Chau, L.W., Ling, H.T., Abdul Rahim, M.N., Zulibrahim, M.Z., Hishammuddin, M.A.H., Abdullah, R., Saari, N.S. and Jausus, N. (2018). 70 By 30. A Greener Better Kuala Lumpur. A summary for policymakers.
Kuala Lumpur Low Carbon Society Blueprint 2030. KL City Hall, Kuala Lumpur. http://www.dbkl.gov.my/index. php?option $=$ com jdownloads $\&$ Itemid $=692 \&$ view $=$ finis h\&cid $=874 \&$ cat $\overrightarrow{\mathrm{d}}=86 \& \mathrm{~m}=0$ \&lang $=\mathrm{ms}$

Hooftman, N., Oliveira, L., Messagie, M., Coosemans, T. and Van Mierlo, J. (2016). Environmental analysis of petrol, diesel and electric passenger cars in a Belgian urban setting. Energies 9: 84. https://doi.org/10.3390/en9 020084

Hu, C.Y., Gao, X., Fang, Y., Jiang, W., Huang, K., Hua, X.G., Yang, X.J., Chen, H.B., Jiang, Z.X. and Zhang, X.J. (2020). Human epidemiological evidence about the association between air pollution exposure and gestational diabetes mellitus: Systematic review and meta-analysis. Environ. Res. 180: 108843. https://doi.org/10.1016/j.envr es.2019.108843

Huang, W., Guo, Y. and Xu, X. (2020). Evaluation of realtime vehicle energy consumption and related emissions in China: A case study of the Guangdong-Hong KongMacao greater Bay Area. J. Clean. Prod. 263: 121583. https://doi.org/10.1016/j.jclepro.2020.121583

International Energy Agency (IEA) (2002). Oil information 2002. IEA/OECD, International Energy Agency (IEA), Paris.

International Energy Agency (IEA) (2019). World energy outlook 2019. International Energy Agency (IEA), Paris https://www.iea.org/reports/world-energy-outlook-2019

Jamhari, A.A., Sahani, M., Latif, M.T., Chan, K.M., Tan, H.S., Khan, M.F. and Tahir, N.M. (2014). Concentration and source identification of polycyclic aromatic hydrocarbons (PAHs) in $\mathrm{PM}_{10}$ of urban, industrial and semi-urban areas in Malaysia. Atmos. Environ. 86: 16-27. https://doi.org/10.1016/j.atmosenv.2013.12.019

Jayaraj, M.D., Abu Hasan, Z.R. and Ahmad, N.M. (2019). Grabcar: Opportunities and challenges for taxi operators. Univ. Malaysia Terengganu J. Undergraduate Res. 1: 4655. http://umtjur.umt.edu.my/wp-content/uploads/sites/1 41/2019/06/JUR-5-GRABCAR-OPPORTUNITIES-ANDCHALLENGES-FOR-TAXI-OPERATORS.pdf

Jerrett, M., Burnett, R.T., Beckerman, B.S., Turner, M.C., Krewski, D., Thurston, G., Martin, R., van Donkelaar, A., Hughes, E., Shi, Y., Gapstur, S., Thun, M. and Pope III, C.A. (2013). Spatial analysis of air pollution and mortality in California. Am. J. Respir. Crit. Care Med. 188: 593-599. https://doi.org/10.1164/rccm.201303-0609OC

Kakouei, A., Vatani, A. and Idris, A.K. (2012). An estimation of traffic related $\mathrm{CO}_{2}$ emissions from motor vehicles in the capital city of Iran. Iran. J. Environ. Health Sci. Eng. 9: 1-13. https://doi.org/10.1186/1735-2746-9-13

Kuala Lumpur City Hall (2004). Kuala Lumpur Structure Plan 2020 (KLSP2020). Federal Town and Country Planning Department, Kuala Lumpur.

Kuala Lumpur City Hall (2017). Kuala Lumpur City Hall Carbon Management Plan Draft 2017-2022. Federal Town and Country Planning Department, Kuala Lumpur.

Laumbach, R.J. and Kipen, H.M. (2014). Respiratory health effects of air pollution: Update on biomass smoke and traffic pollution. J. Allergy Clin. Immunol. 129: 3-11. https://doi.org/10.1016/j.jaci.2011.11.021 
Lawson, D.R. (1993). 'Passing the test'- Human behaviour and California's smog check program. J. Air Waste Manage. Assoc. 43: 567. https://doi.org/10.1080/1073161 X.1993.10467226

Lin, M. and Dula, C. (2016). Grab taxi: Navigating new frontiers. Asian Management Insights 3: 40-45. https://ink.library.smu.edu.sg/sis_research/3433

Ling, H.L.O., Ting, K.H., Shaharuddin, A., Kadaruddin, A. and Yaakob, M.J. (2010). Air quality and human health in urban settlement: Case study of Kuala Lumpur city. 2010 International Conference on Science and Social Research (CSSR 2010), pp. 510-515. https://doi.org/10.1109/CSS R.2010.5773831

Ling, H.L.O., Ahmad, S., Aiyub, K., Jani, Y.M. and Hwa, T.K. (2012). Urban air environmental health indicators for Kuala Lumpur City. Sains Malays 41: 179-191. http://journalarticle.ukm.my/3289/

Luyten, L.J., Saenen, N.D., Janssen, B.G., Vrijens, K., Plusquin, M., Roels, H.A., Debacq-Chainiaux, F. and Nawrot, T.S. (2018). Air pollution and the fetal origin of disease: A systematic review of the molecular signatures of air pollution exposure in human placenta. Environ. Res. 166: 310-323. https://doi.org/10.1016/j.envres.2018.03. 025

Madireddy, M., De Coensel, B., Can, A., Degraeuwe, B., Beusen, B., De Vlieger, I. and Botteldooren, D. (2011). Assessment of the impact of speed limit reduction and traffic signal coordination on vehicle emissions using an integrated approach. Transp. Res. Part D 16: 504-508. https://doi.org/10.1016/j.trd.2011.06.001

Malaysian Energy Commission (2017). Malaysia energy statistics handbook 2017. https://meih.st.gov.my/docume nts/10620/b1849938-e2e9-49fe-a789-9240df14cd75

Masjuki H.H., Karim M.R. and Mahlia T.M.I. (2004). Energy use in the transportation sector of Malaysia. Consultancy Unit, University of Malaya, Kuala Lumpur. https://www.scribd.com/doc/10049213/Energy-Use-inthe-Transportation-Sector-of-Malaysia

Mathew, T.V. (2014). Fuel consumption and emission studies IIT. Bombay, pp. 1-25. https://www.civil.iitb.ac.i n/ vmtom/nptel/583_FuelEmi/web/web.html

Md Khalili, S.S. (2019). 5 reasons why you shouldn't dream of owning an electric vehicle in Malaysia. New Straits Times. https://www.nst.com.my/cbt/2019/08/509085/5reasons-why-you-shouldnt-dream-owning-electricvehicle-malaysia

Mohd Shafie, S.H. (2019). Impact of traffic pollution on physical and social environment in Kuala Lumpur. Unpublished $\mathrm{PhD}$ Thesis. Universiti Kebangsaan Malaysia.

New Straits Times (2017). Grab Malaysia receives e-money licence. https://www.nst.com.my/business/2017/12/3123 51/grab-malaysia-receives-e-money-licence

Ntziachristos, L. and Samaras, Z. (2000). Speed dependent representative emission factors for catalyst passenger cars and influencing parameter. Atmos. Environ. 34/27: 46114619. https://doi.org/10.1016/S1352-2310(00)00180-1

OECD (2019). Organization for economic co-operation and development statistic. https://stats.oecd.org
Omar Kamal, S.M. (2015). Analysis of performance and emission of different petrol fuel on small duty engine at various ambient temperatures. Master Thesis of Mechanical Engineering. Universiti Tun Hussein Onn Malaysia, Malaysia.

Ong, H.C., Mahlia, T.M.I. and Masjuki, H.H. (2011). A review on emissions and mitigation strategies for road transport in Malaysia. Renewable Sustainable Energy Rev. 15: 3516-3522. https://doi.org/10.1016/j.rser.2011.05.006

Public Work Department (2014). Road Traffic Volume $(R T M V)$. Ministry of Works, Malaysia

Ramalingam, M. and Fuad, A.A. (2014). Short communication: Sulphur levels and fuel quality in Peninsular Malaysia. ASEAN J. Sci. Technol. Dev 32: 5259. https://doi.org/10.29037/ajstd.11

Rostampour, V. (2010). The perth vehicle emissions inventory 2006 - 2007: Technical report. https://www.der.wa.gov.au/images/documents/yourenvironment/air/publications/Perth_Vehicle_Emissions Inventry_2006-2007.pdf

Saboori, B., Sapri, M. and Baba, M. (2014). Economic growth, energy consumption and $\mathrm{CO}_{2}$ emissions in OECD (Organization for Economic Co-operation and Development)'s transport sector: A fully modified bidirectional relationship approach. Energy 66: 150-161. https://doi.org/10.1016/j.energy.2013.12.048

Saija, S. and Romano, D. (2002). A methodology for the estimation of road transport air emissions in urban areas of Italy. Atmos. Environ. 3636: 5377-5383. https://doi.org/ 10.1016/S1352-2310(02)00488-0

Salleh, M.R., Mahmud, A.J. and Khathri, A.M. (2018). Experimental investigation the RON 95 and RON 97 on the performance and emissions. Polytechnic \& Community Collage Journal of Engineering and Technology, Special Issues on CoT 2018 22-33. http://myjms.moe.gov.my/in dex.php/PMJET/article/view/3556

Samaras, Z., Zachariadis, T., Joumard, R., Vernet, I., Hassel, D., Weber, F.J. and Rijkeboer, R. (1998). Alternative short test for inspection \& maintenance of in-use cars with respect to their emissions performance. Int. J. Veh. Des. 20: 292-303. https://doi.org/10.1504/IJVD.1998.001837

Shaari, M.S., Yusuf, A.H., Abashah, A. and Pei, T.L. (2018). Can retail selling prices of petrol and diesel trigger inflation in Malaysia? MATEC Web of Conferences 150: 05070. https://doi.org/10.1051/matecconf/201815005070

Shahbaz, M., Loganathan, N., Sbia, R. and Afza, T. (2015). The effect of urbanization, affluence and trade openness on energy consumption: A time series analysis in Malaysia. Renewable Sustainable Energy Rev. 47: 68393. https://doi.org/10.1016/j.rser.2015.03.044

Shammut, M., Cao, M., Zhang, Y., Papaix, C. and Gao, Y.L. (2019). Banning diesel vehicles in London: Is 2040 too late? Energies 12: 3495. https://doi.org/10.3390/en12183 495

Shehab, M. and Pope, F. (2019). Effects of short-term exposure to particulate matter air pollution on cognitive performance. Sci. Rep. 9: 8237. https://doi.org/10.1038/s 41598-019-44561-0

Shuid, S. (2004). Urbanization and housing in Kuala 
Lumpur city centre. $19^{\text {th }}$ EAROPH World Planning and Housing Congress 2004, Melbourne Australia. pp. 1-14. http://irep.iium.edu.my/4159/1/earoph2004.pdf

Stanislaus A., Marafi, A. and Rana, M.S. (2010). Recent advances in the science and technology of ultra low sulphur diesel (ULSD) production. Catal. Today 153: 168. https://doi.org/10.1016/j.cattod.2010.05.011

Su, J.G., Apte, J.S., Lipsitt, J., Garcia-Gonzales, D.A., Beckerman, B.S., de Nazelle, A., Texcalac-Sangrador, J.L. and Jerret, M. (2015). Populations potentially exposed to traffic-related air pollution in seven world cities. Environ. Int. 78: 82-89. https://doi.org/10.1016/j.e nvint.2014.12.007

Su, W., Wu, X., Geng, X., Zhao, X., Liu, Q. and Liu, T. (2019). The short-term effects of air pollutants on influenza-like illness in Jinan, China. BMC Public Health 19: 13-19. https://doi.org/10.1186/s12889-019-7607-2

Teriman, S., Yigitcanlar, T. and Mayere, S. (2010). Chapter 11 Sustainable urban infrastructure development in South East Asia: Evidence from Hong Kong, Kuala Lumpur and Singapore. In Sustainable urban and regional infrastructure development: Technologies, applications and management, Yigitcanlar, T. (Ed.), pp. 152-164, IGI Global, Information Science Reference, United States of America. https://doi.org/10.4018/978-1-61520-775-6.ch011

The Automobile Association (2020). EURO Emissions Standards. Limits to improve air quality and health. https://www.theaa.com/driving-advice/fuels-environment/ euro-emissions-standards

The Central Bank of Malaysia (2011). Central Bank of Malaysia Annual Report 2010. Kuala Lumpur: Central Bank of Malaysia Publishing. https://www.bnm.gov.my/i ndex.php?ch=en_publication\&pg=en_ar\&ac $=16 \&$ lang $=$ en

Thorpe, A. and Harrison, R.M. (2008). Sources and properties of non-exhaust particulate matter from road traffic: A review. Sci. Total Environ 400: 270-282. https://doi.org/10.1016/j.scitotenv.2008.06.007

U.S. Energy Information Administration (EIA) (2004). DOE: http://www.eia.doe.gov/emeu/ipsr/contents.html

U.S. Energy Information Administration (EIA) (2005). Household vehicles energy use: Latest data \& trends. DOE/EIA-0464-2005. Energy Information Administration (EIA), U.S. Department of Energy. U.S. Department of Energy, Washington D.C. https://www.eia.gov/consump tion/residential/pdf/046405.pdf

U.S. Energy Information Administration (EIA) (2014). Short-term Energy Outlook (STEO). https://www.eia.go v/outlooks/steo/archives/jun14.pdf

United States Environmental Protection Agency (U.S. EPA) (2011). Compilation of Air Pollutant Emission Factors, Volume I: Stationary Point and Area Sources AP-42. United States Environmental Protection Agency, USA.

United Nations (UN) (1991). Energy Statistics: A Manual for Developing Countries, Series F, No. 56, United Nations, New York.

Wei, Y., Wang, Yan, Di, Q., Choirat, C., Wang, Yun,
Koutrakis, P., Zanobetti, A., Dominici, F. and Schwartz, J.D. (2019). Short-term exposure to fine particulate matter and hospital admission risks and costs in the Medicare population: Time stratified, case crossover study. BMJ 367: 16258. https://doi.org/10.1136/bmj.16258

Winkler, S.L., Anderson, J.E., Garza, L., Ruona, W.C., Vogt, R. and Wallington, T.J. (2018). Vehicle criteria pollutant $\left(\mathrm{PM}, \mathrm{NO}_{\mathrm{x}}, \mathrm{CO}, \mathrm{HCs}\right)$ emissions: How low should we go? npj Clim. Atmos. Sci. 1: 23. https://doi.org/ 10.1038/s41612-018-0037-5

World Bank (2014). World Development Indicators. World Bank, Washington, US. https://datacatalog.worldbank.or $\mathrm{g} /$ dataset/world-development-indicators

World Health Organization (WHO) (2018). World health statistics 2018: Monitoring health for the SDGs, sustainable development goals. World Health Organization. https://apps.who.int/iris/handle/10665/272596

Wu, L., Ci, Y., Wang, Y. and Chen, P. (2020). Fuel consumption at the oversaturated signalized intersection considering queue effects: A case study in Harbin, China. Energy 192: 116654. https://doi.org/10.1016/j.energy.20 19.116654

Yang, Z., Liu, Y., Wu, L., Martinet, S., Zhang, Y. and Andre, M. (2020). Real-world gaseous emission characteristics of Euro $6 \mathrm{~b}$ light-duty petrol- and diesel-fueled vehicles. Transp. Res. D 78: 102215. https://doi.org/10.1016/j.trd.2 019.102215

Yunus, S.M., Hodin, N.S., Zulkifli, F.H., Mustaffa, N. and Osman, S.A. (2019). FMC the comparative analysis between gasolines RON95, RON97 and RON100 on engine performance. Fuel, Mixture Form. Combust. Proc. 1: 1-7. https://fazpublishing.com/fmc/index.php/fmc/art icle/view/12

Zachariadis, T., Ntziachristos, L. and Samaras Z. (2001). The effect of age and technological change on motor vehicle emissions. Transp. Res. Part D. 6: 221-227. https://doi.org/10.1016/S1361-9209(00)00025-0

Zainuddin, A. (2019). Electric vehicles gain momentum in Malaysia, but power supply remains a problem. The Malaysian Reserve. https://themalaysianreserve.com/201 9/07/03/electric-vehicles-gain-momentum-in-malaysia

Zhang, T., Omran, B.A. and Cobanoglu, C. (2017). Generation Y's positive and negative eWOM: Use of social media and mobile technology. Int. J. Contemp. Hosp. Manage. 29: 732-761. https://doi.org/10.1108/IJCHM-10-2015-0611 Zhu, W., Wang, J., Zhang, W. and Sun, D. (2012). Shortterm effects of air pollution on lower respiratory diseases and forecasting by the group method of data handling. Atmos. Environ. 51: 29-38. https://doi.org/10.1016/j.atm osenv.2012.01.051

Received for review, February 24, 2020 Revised, September 14, 2020 Accepted, October 12, 2020 